Journal of Economics and Behavioral Studies

Vol. 3, No. 4, pp. 235-248, Oct 2011 (ISSN: 2220-6140)

\title{
Analysis of Convergence of Fiscal Variables in Sub-Saharan African Countries (1981-2007): A Stochastic Technique
}

\author{
${ }^{*}$ OSENI Isiaq Olasunkanmi ${ }^{1}$, OLOMOLA Philip Akanni² \\ ${ }^{1}$ Bells University of Technology Otta, Ogun State \\ 2Obafemi Awolowo University Ile-Ife, Osun State \\ *osenibells@ymail.com
}

\begin{abstract}
The study examined the analysis of convergence of fiscal variables among Sub-Saharan Africa (SSA) countries for the period 1981-2007. Secondary time-series data were used for the study and analysed using econometric techniques. The results showed that there were convergence in Burkina Faso, Cameroon, Nigeria, Rwanda, Sierra Leone and Uganda while there were divergence in Burundi, Kenya, Mauritius and South Africa. The study concluded that only Burkina Faso, Cameroon, Nigeria, Rwanda, Sierra Leone and Uganda could form Economic and Monetary Union (EMU) as a result of their convergence of Fiscal Variables.
\end{abstract}

\section{Keywords: Fiscal Variables, Convergence, Cointegration, Stochastic, Sub-Saharan African Countries}

\section{Introduction}

Convergence has been at the heart of a wide-ranging debate in the growth literature for some time (see Temple, 1999; Durlauf and Quah, 1999 and Islam, 2003). Intuitively, the term 'convergence' suggests a process whereby poor countries catch up with richer countries in terms of income levels. The convergence literature is therefore concerned with an issue of vital importance in economics- it deals with the distribution of riches across the world and its evolution over time. Arguably, this explains the sizeable efforts that the economic profession has devoted to the empirical study of convergence. The phrase, "economic convergence" means that the variations of economic variables, among the groups of countries and regions, are diminishing. However, if economic growth reduces income differences between regions, convergence takes place. If growth increases income differences between regions, then it is called divergence. Although the pioneering convergence studies have examined whether economic growth reduces income differences between regions, studies have also investigated whether convergence takes place in several macroeconomic indicators such as inflation rates, interest rates and unemployment rates.

The process of economic convergence at the country level has been analyzed extensively in the literature (See Barro and Sala-i-Martins (1992); Cappelen et al (2001)); Fischer et al (2007). The analysis of convergence in fiscal variables have been less thoroughly investigated empirically in the literature either at specific or cross country level due to the fact that the theoretical literature is still not clear about the contribution of fiscal policy variables, especially taxation and other distributional measures to long-term growth and convergence is SSA countries additionally because of lack of reliable and consistent fiscal data the countries level. When deciding on measures that affect country transfers, policy makers need to take into account the costs in terms of the distortions they induce on the side of the net payers as well as the net recipients. In particular, the pursuit of country redistribution objectives must give due consideration to the cost of forgone or impeded economic growth.

There have been many empirical studies and large literature about the subject of convergence (Cashin (1995); Cheshire and Magrini (2000). As an extension of the Harrod-Domar and Solow's model, according to the neo-classical growth theory, a closed country that has no external activity and with low saving rates develops slower than a country with higher saving rates. As a result, the income level of the country that has low saving rates, reaches the level of the lower income level countries. However, due to commercial activities and foreign capital, the income level of a country that has an open economy reaches the income level of countries that have a higher income and the country with low income converges to the level of rich countries. According to the neo-classical theory, the reasons for the convergence between regions are the mobility of the production factors and the capital reserves. Hence, factors like employment, capital, advances in technology, 
employment between regions, and mobility of the production factors (migration), human capital (education), and public expenditures have been used as the determinants of the regional income differences.

In investigating fiscal convergence, a budget deficit appears to be one of the most important themes at the core of actual macroeconomic policymaking. Since the 1980s the negative effects of budget deficits on the economy have motivated a number of studies aimed at shaping many macroeconomic adjustment and/or stabilization policies worldwide (Jacobs et al., 2002). Experiences show that widening deficits have been accompanied by spiraling debt and inflation in some developing countries particularly in Latin America and Sub-Saharan Africa. Moreover, in recent years, accumulated budget deficits over time have led to public debt reaching its highest level even in developed countries. This makes spiraling public debt a worldwide issue that puts national economies under pressure, given the relationships that exist between the level of public debt and some macroeconomic aggregates (such as national income, inflation, the foreign exchange rate, investment, and national saving); and prompts the question of fiscal sustainability (Archibald and Greenidge, 2003). In addition, over the last two decades, developing countries have been characterized a decline -at the best a stagnation- of their per-capita GDPs, though some of them experienced a surge in growth during the 1990s. Divergence in the standard of livings is observed, meaning that some countries are escaping from poverty while others are trapped. Thus, convergence across countries can be explained as a result of difference in economic structures experienced by different countries, which implies that the countries evolve along different long-run paths.

Previous studies have intensively explored the effect of income convergence on economic growth across SSA countries. Ben- Hammouda et al. (2007) investigated macroeconomic convergence in various African regions and its relationship on economic growth between 1981 and 2003. The study used both sigma and beta convergence to investigate the convergence in macroeconomic variables in the regions. Surprisingly, only few countries converged to their initial per capita income in the income convergence test. On the other hand, the study employed budget balance for fiscal balance and found little or no countries converged to their initial values except the ECOWAS countries like Benin, Burkina Faso, Cote d'Ivoire, Gambia, Mali, Nigeria, Sierra Leone; CEMAC like Cameroon, Chad, Congo, Rep, Eq. Guinea; and UEMOA like Mali, Benin, Niger, Burkina Faso, Togo; countries whose dispersion of fiscal balance remained very low, ranging from 4 percent to 6 percent during the period studied. Thus, this paves room for the formation of the aforementioned economic integration in the African countries. Although, the study had failed to consider other fiscal variables such as productive expenditure and distortionary taxes which most of the growth theories believed so important in the growth effect of any countries (Bleaney et al, (2001), Endogenous growth theory ), this study intends to fill this gap.

Therefore, this study analyzed the convergence of fiscal variables as a benchmark for the formation of Economic and Monetary Union (EMU) in SSA countries. It was against this background the following questions were raised: Is there convergence in fiscal variables among the Sub-Saharan Africa Countries? To what extent are fiscal variables converged in the long-run among the Sub-Saharan Africa countries? The rest of the paper is structured as follows: in addition to the introduction, section two entailed the theoretical literature while section three discussed the methodology cum theoretical framework. Section four presented the results and discussion while section five contains conclusion and policy recommendations.

\section{Literature Review}

Macroeconomic convergence is a concept that has gained popularity for a variety of reasons. Proponents of economic convergence say that coordination of economic policies leaves countries better off without others being worse off. By cooperating to coordinate policies to take account of spillovers, each country may better achieve its specific objectives. Convergence is a prelude and is crucial to economic integration. It often makes sense for countries to coordinate their economic policies to generate benefits that are not possible otherwise. For instance, cooperation in international trade by setting zero tariffs against each other, countries are likely to benefit relative to the case when countries attempt to secure short term advantages by setting optimal tariffs. Benefit may accrue to countries which liberalize labour and capital movements across borders, coordinate fiscal and monetary policies; and resource allocation. 
Economic convergence exists when member countries tend to reach a similar level of development and wealth. According to Solow's economic growth model, an economy converges towards a steady state due to diminishing returns to investment in physical capital. Solow assumed that countries were equal in all aspects but their initial levels of per capita income and poor countries had higher marginal capital productivity than rich countries, thus would eventually catch up. Solow's assumption was affirmed by the findings of (Barrientos, 2007) where convergence was confirmed among developed countries. However, it was concluded that convergence does not apply among the poorest world economies. Olivier et al (2000) investigated whether economic, financial and monetary integration on the one hand, and institutional factors on the other, may have led to gradual convergence in key fiscal variables across the euro area over the recent period, bringing fiscal positions closer together. Boldrin and Canova (2001) investigated the role of European regional policies in promoting convergence in output per capita during the period 1980 to 1996. They concluded that there is no evidence that structural and cohesion funds regions behave differently from others or display any form of systematic catching-up with the rest of regional income distribution. Martin (1999) found some empirical support for the convergence model across the European regions during the 1980s and early 1990s, but concludes that a fast, automatic catch-up process was unlikely and that regional policy instruments could have a positive impact on regional convergence.

Anthony (2003) examined Winner and Losers from Regional Integration Agreements in Economic Community of West African between 1972 and 1997; generally include all low income countries and found divergence in customs union with low income countries. He formulated three models with two small countries and the rest of the world which were: Diagrammatic analysis including competitive advantage and trade creation and diversion; Multi good Ricardian trade model and Heckscher-Ohlin structure with production differentiation. The factor affecting the existence of the convergence was the level of competitive advantage between number countries; a few nations would have an extreme competitive advantage which others would have an intermediate advantage. This study suggested that Low per capita income countries should join customs unions agreements with more development countries that possess a highly skilled work force (North-South Agreement). Kaufman et al. (2003) examined the role of federal transfers in the process of economic convergence across Canadian provinces by looking directly at the impact of equalization payments on growth, and indirectly at the impact of employment insurance schemes on migration. They found that the equalization payments might have helped spur the process of output convergence, while the employment support scheme seems to have deterred convergence by discouraging migration across Canadian provinces. Second, and related to the first approach, the role of fiscal policy for the process of convergence might be investigated by looking at $\sigma$-convergence, or how measures of income and output dispersion were influenced by fiscal variables.

Abdoul Aziz (2004) investigated Growth and Convergence in WAEMU Countries for the period 1965 to 2002. This study found convergence occurring across the WAMEU both absolutely and conditionally. When country specific variable were omitted the economies tend to converge at 6 percent in year. The growth was even faster when countries had similar investment ratios. The difference between factors accumulation and TFP growth was also explored. Panel data models were used in this empirical testing because of its advantage over pure cross section or time series data. The author explained how estimates were more difficult to establish with panel data, and user mean group and pooled means group estimates the Solow model was also examined and the convergence in the WAEMU does not fit the traditional catch up perdition due to the fact that different convergence groups were explained including the idea of club convergence where the initial conditions of countries were the same. The paper found that investment in human capital was an important determinant of per capita output growth. The study claimed that counties like Cote d'Ivoire and Senegal, there should be less emphasis on macroeconomic adjustment and other countries should focus on political stability and sound government spending. In Turkey, Ocal and Ozyıldırım (2004) investigated income convergence and found important in income differences between its regions and its cities. Thus, no convergence analysis on public expenditure and tax revenue which are fiscal variables in Turkey, hence this study intends to shed more light on this in SSA countries. Darvas et al (2005), investigated the relationship between fiscal divergence(increase in convergence) and business cycle synchronization using a panel of 21 OECD countries and 40years of annual data, they found that countries with similar government budget positions tend to have business cycle that fluctuate more closely. That is, fiscal convergence (in form of persistently similar ratios of 
government surplus/deficit to GDP) was systematically associated with more synchronized business cycles. They also found evidence that reduced fiscal deficits increased business cycle synchronization.

Gilles and Gilles (2005) tested real convergence in the ECOWAS counties in presence of heterogeneous long run growth using panel Data between 1985 and 2003. No real convergence was found among the member and there was even divergence. The model showed that countries had both short and long term structural heterogeneity and thus different from previous studies that assumed a homogenous long run growth path. The study identified that Niger, Nigeria and Togo were said to lag behind because of the poverty trap issue. The author claimed that the only way to eliminate structural heterogeneity was through a coordination of policies which was already on the agenda for WAEMU and ECOWAS countries and their conditions for nominal convergence. Mark (2005) examined the long run output convergence associated with International and some new evidence for selected African countries. In the study, CFA, SACU, and ECOWAS countries were tested for long run per capita income convergence between 1960 and 2000. They found that there was strong long run convergence in both CFA and SACU with the latter having most convergence. However, there was no evidence of long run convergence in ECOWAS. It appeared that monetary unions did better than trade agreement in convergence. There were also difference levels of convergence within the grouping; for example, countries that were originally stationary in the CFA did not experience strong convergence due to the fact that the size of the group did not appear to greatly affect convergence; large group did just as well as smaller group. This test was based on whether the first largest principle component based on benchmark deviation from base countries output is stationary or not. The author claimed that unit root testing of the first LPC based on income differential offer a number of advantages over existing tests of convergence because the choice of base country was not as important. The study thus suggested that research should also reflect on why some regional agreements are better at producing convergence than others.

Jannie (2006) examined analysis of macroeconomic convergence in SADC using a simple data of inflation rates and GDP to determine whether or not a monetary union could exist if all the macro convergence criteria were not met. The author compared the current situation to that of the EU and found that SADC countries had mixed result in meeting their goals for a monetary union which must be met by 2008. Some countries achieved their goals in 2004 and had maintained this progress, while other has not been as successful. The author argued that meeting these criteria were not vital to establishing the union and cites the EU as an example. The author argued that macro economic convergence goals have to be views properly in order for true convergence to occur instead of thinking of them as a condition to enter an agreement; they should be viewed as a constant goal, even in the EU. The study claimed that monetary union is still possible in SADC even if all the countries do not meet their goals.

Sumar and Jerome (2007) used various methods that allow a quantitative assessment of the degree of financial integration and based on interest rate data bank structure data, mergers and acquisition data and bank concentration data convergence was tested for in the interest rate spreads and found that there was some of price convergence in average interest rate spreads. However the empirical evidence was not supposed by an increase or cross border flows in retails loans and deposits. Price convergence might merely reflect excess liquidity in the region. Bank competition on CEMAC was limited, which limits further integration. The author rose that a number of factors could affect convergence in the financial markets which include: increase in bank deposits because of settlement of government arrears; a scarcity of investment opportunist has lead to high liquidity and limited lending opportunities exist. The study claimed that price convergence implies that price differential for the same financial service should be reduced and down to a level explained mostly by the existence of arbitrage or transportation costs.

Bouvet (2007) sought to explain regional output inequality within 13 EU countries during the period 19772003, and used social transfers as an explanatory fiscal variable. Somewhat surprisingly, social transfers were found significant in reducing output inequality only when Greece, Spain and Portugal (countries that received the largest support from the EU) were excluded from the analysis. Third, some insights as to the impact of fiscal policy on income convergence might be revealed by comparing the convergence rates across various income indicators, such as per-capita GDP, personal income, and personal disposable income. The difference between the last two reflects the effect of tax and redistribution policies. In sub-Saharan Africa countries, empirical evidence has shown that convergence could only occur if the following conditions were met: (i) low 
rate of inflation is desirable, (ii) a level of debt that is sustainable and desirable with a sensible fiscal management, (iii) moreover, a macroeconomic convergence may be sensible on efficiency grounds if the condition prevailing in the Common Monetary Area in Southern Africa could be extended to other countries in the SSA regions. But institutional integration such as measures towards macroeconomic convergence go hand in hand with economic integration and lack of economic integration among SSA countries could be a major constraint on the policy of convergence. In addition, Buiter (2000) argued that in sub-Saharan Africa countries, thorough assessment of the desirability of macroeconomic convergence and an economic analysis of cost and benefit have been analyzed until these costs and benefits are recognized and the constraints on convergence identified, the path to macroeconomic convergence would be arduous.

However, none of these studies has empirically examined the convergence of fiscal variables in Sub-Saharan Africa countries. In addition, most of the authors failed to hypothesize the extent of the convergence. It should be noted that most of the authors applied the ordinary least square (OLS) technique to estimate their models. Most of the studies reviewed focuses on fiscal convergence in developed countries while studies from developing countries are scanty most especially in sub-Saharan Africa countries, this study contributes to the existing literature by examining convergence in fiscal variables in SSA countries. The study however is an improvement on the studies reviewed in the sense that it applies other test of diagnoses to the time series data used in order to account for robustness in regression results.

\section{Methodology}

Theoretical Framework: This study employed the standard Ramsey framework in which the consumption path of a representative consumer is obtained by maximizing an inter-temporal utility function over an infinite horizon that assumes that the number of households $L$ (as well as their size) stays constant and each is endowed with one unit of labour per period of time. The household income comprises labour income ( $w$ denotes the wage rate) and capital income (the amount of capital owned by the household is $\mathrm{K}$; the net real rate of return is $r-\delta$ ). There are $n$ producers each producing output $(y)$ according to the production function:

$$
y=A k^{\alpha} g^{\beta}
$$

Where k represents private capital and $g$ is a publicly provided input (per capita). There are therefore constant returns to total (public plus private) 'capital' inputs, $k+g$. The government also produces consumption ('unproductive') goods, $g_{c}$, which enter consumers' utility functions but have no effect on production. The government balances its budget in each period by raising a proportional tax on output at rate $\tau$ and lump-sum taxes of $\mathrm{L}$, giving the constraint:

$$
n g+C=L+\tau n y
$$

Where $\mathrm{n}$ is the number of producers in the economy and $\mathrm{C}$ is government consumption, which is assumed unproductive. Theoretically, a proportional tax on output affects private incentives to invest but lump sum tax does not. Subject to a specified utility function, Barro (1990) and Barro and Sala-i-Martin (1992) derive the long run growth rate $(y)$ in this model as:

$$
\gamma=\varphi(1-\tau)(1-\alpha) A^{\frac{1}{\beta}}\left(\frac{g}{y}\right)^{\frac{\alpha}{\beta}}-\mu
$$

Where $\varphi$ and $\mu$ are parameters in the utility function. Equation (3) shows that the growth rate is decreasing function of distortionary tax rates $(\tau)$ and increasing function of government productive expenditure $(g)$, but is unaffected by non-distortionary taxes $(L)$ and unproductive government expenditure $(C)$. The specification above assumes the government balances its budget each period, an assumption that is unlikely to hold in reality especially in the less developed countries. This study follows the empirical model of Bleaney et al (2001) in which they take a more practical view by assuming a non-balancing government budget constraint in some periods. Taking this into account, we can re-write (eq3) to obtain the following expression.

$$
n g+C+b=L+\tau n y
$$

Where $b$ is the budget deficit/surplus in a given period. Since $g$ is productive, its predicted sign is positive, but $\tau$ is negative as it distorts incentives of private agents. C and L are hypothesized to have zero effects on 
growth. Similarly, the effect of $\mathrm{b}$ is expected to be zero as long as Ricardian equivalence holds, but may be non-zero otherwise (see Bleaney et al (2001). We specify our growth equation in the spirit of Kneller et al (1999) by considering both fiscal $\left(f_{i t}\right)$ and non-fiscal $\left(n f_{i t}\right)$ variables so that the growth equation becomes,

$$
y_{t}=\alpha+\sum_{i=1}^{k} \beta_{i} n f+\sum_{j=1}^{m} \psi_{i} f_{j t}+\varepsilon_{i t}
$$

Where $y_{t}$ is the growth rate of output, $f$ is the vector of fiscal variables, $n f$ is the vector of non-fiscal

variables, and $\varepsilon_{i t}$ are disturbance terms. In theory, if the budget constraint is fully specified, then $\sum_{j=1}^{m} f_{j t}=0$ because expenditures must balance revenues. To avoid this, we need to omit at least one element of $f$ (say $f_{m}$ ) to avoid perfect collinearity (See Bleaney et al (2001). Theoretically, the omitted element has no effect on growth, thus, in order to select any other, we introduce a substantial bias in parameter estimates.

Consequently, we can re-write equation 5 in the following form.

$$
y_{t}=\alpha+\sum_{i=1}^{k} \beta_{i} n f+\sum_{j=1}^{m-1} \psi_{i} f_{j t}+\psi_{m} f_{m t}+\varepsilon_{i t}
$$

Omitting $f_{m t}$ from equation 6, we obtain the new growth equation as follows:

$$
y_{t}=\alpha+\sum_{i=1}^{k} \beta_{i} n f+\sum_{j=1}^{m-1}\left(\psi_{i}-\psi_{m}\right) f_{j t}+\varepsilon_{i t}
$$

The growth equation denoted by (7), as specified in Kneller et al (2001), constitutes the relationship between $y_{t} ; n f ;$ and $; f_{j t}$. The correct interpretation of each estimated fiscal parameter is the effect of a unit change in the relevant fiscal variable offset by a unit change in the element or elements omitted from the regression, Kneller et al (2001). In terms of the fiscal categories described above, for example, the parameter on productive expenditure would be expected to be higher if it is implicitly financed by omitting nondistortionary taxation rather than by omitting distortionary taxation-because $\psi_{j}=\psi_{j}-\psi_{m}$ is expected to be less negative, or zero. The problem is not solved by omitting many elements of the government budget constraint from the regression instead of just one; rather it becomes harder to identify precisely what is the assumed implicit financing. More precisely, if the null hypothesis is rejected, parameter estimates can be obtained if the neutral elements are eliminated from the model i.e. $\psi_{j}=\psi_{j}-\psi_{m}, \psi_{j}=0$; we test this.

Convergence to Steady State Framework: According to Barro and Sala-i-Martin (1992) using endogenous growth model of Solow (1956), an expression for the speed of convergence at steady state is expressed as the first order linear differential equation, with reference to fiscal equation-fiscal convergence can be captured as follows if fiscal equation is expressed as;

$$
\sum_{j=1}^{n} f_{j t}=F\left(\varphi \sum_{j=i}^{n-1} f_{j t-1}\right)
$$

Then an expression of fiscal convergence is as follows:

$$
\frac{d \operatorname{Inf}}{d t}=\ell\left(\operatorname{Inf}-\operatorname{Inf}_{t}\right)
$$

Where $\ell$ is a parameter for the speed of convergence. A solution to equation (9) is written as:

$$
\operatorname{In} \sum_{j=1}^{n} f_{t}-\operatorname{In} \sum_{j=1}^{n-1} f_{0}=\left(1-e^{-\ell t}\right)\left[\varphi \sum_{j=1}^{n-1} f_{j t}-\operatorname{In} \sum_{j=1}^{n-1} f_{0}\right.
$$

Incorporating fiscal convergence equation above in equation 7 gives the estimable model as shown below:

$$
\operatorname{Infis}_{t}=\alpha+\operatorname{In} \sum_{i=1}^{k} \beta_{i} n f+\left(1-e^{-\ell t}\right)\left[\varphi \sum_{j=1}^{n-1} f_{j t}-\operatorname{In} \sum_{j=1}^{n-1} f_{0}\right.
$$


Since the speed of convergence, $\ell$, is a constant, equation (10) states that fiscal variables are functions of the initial level of their growth rates. Again, conditional convergence is captured with the negative relationship between initial level of fiscal variables and their present forms. Therefore, the sign of $\ell$ is expected to be negative, a priori. Once, the sign of $\ell$ is negative, it means that fiscal variables converge to their growth rates in the long-run, otherwise diverge (positive), Barro and Sala-i-Martin (1992). Thus, equation (11) captures the analysis of convergence in fiscal variables.

Model Specification: The analysis of convergence has been an active as well as a challenging field of interest since the late 1980s. In order to analyze the convergence of fiscal variables among the Sub-Saharan African countries, this study built its model on new theory of trade (endogenous growth theory base) which is based on the simple game theoretical framework where agents agreed on the long-term goals as posits by Islam (2003) which shows that fiscal constraint lead to implicit coordination characterized by lower deficit. The model provides an argument for the benefits of fiscal convergence for acceding country and the stability of the existing monetary union. In this respect, we specified the convergence equation as follow based on endogenous growth theory.

Convergence Equation: To determine the nature and extent of convergence in fiscal variables among the SSA countries, the study employed conditional stochastic beta convergence. According to Sala-i-Martin (1996), he argued that the neoclassical model prediction of convergence depends on the main assumption that "the only difference across countries lies in their initial level of the variable in question". In reality, however, economies may differ in their level of technology, their propensities to save, or their population growth rates. If different economies have different technological and behavioural parameters, then they tend to have different steady state.

Thus, conditional stochastic beta convergence allows testing of convergence among countries with different steady state. And one way of performing this test is to hold the steady state of each economy constant by introducing a vector of other explanatory variables in the equation (Barro and Sala-i-Martin, (1992), and Mankiw et al (1992)). Following the work of Barro and Sala-i-Martin (1995) and Islam (1995), we specify the fiscal convergence equation for a group of countries $i=1,2, \ldots \mathrm{N}$ in SSA as follows:

$\Delta$ Infiscal $_{i t}=\alpha_{N T}+\beta$ Infiscal $_{i t-1}+\sum_{i=1}^{N-1} x_{i}+\varepsilon_{i t}$

Where fiscal is the relevant fiscal variables which are productive expenditure, unproductive expenditure, distortionary tax, non-distortionary taxes, fiscal deficit/surplus, other expenditures and other revenue. Thus, growth theory believes that fiscal balance, productive expenditure and distortionary tax only contribute to growth of the economy which is the focus of this study (BKG, 1999), $\alpha$ and $\beta$ are parameters and $\varepsilon$ is a classical error term. The parameter $\beta$ captures convergence $(\beta<0)$ from short-run disequilibrium towards the steady-state, $\mathrm{x}_{t}$ captures control/explanatory variables.

In order to capture the extent of the convergence of fiscal variables (length of time), the study employed the equation of the speed of convergence. From equation (12), the value of $\beta$ is used to estimate the time-lag and the equation is specified as follows:

$\frac{1}{T} \log \left[f i s(T / f i s(0)]=\chi+\frac{\left(1-e^{-\beta T}\right)}{T} \cdot \log \left[\overline{f i s}^{*} / \overline{f i s}(0)\right]\right.$

However, equation (13) can be reduced to:

$e^{-\beta t}=\frac{f i s(t)-f i s^{*}}{f i s(0)-f i s^{*}}$

The term on the right-hand side of equation (14) is the fraction of the distance to the balanced growth path that remains to be traveled. Thus, solving for $t$ in equation (14), therefore, we find the log of both sides and equation (14) becomes:

$t=-\frac{\operatorname{In}\left[\mathrm{fis}_{t}-f i s^{*}\right]-\operatorname{In}\left[\mathrm{fis}_{t-1}-f i s^{*}\right]}{\beta}$ 
Since $\beta=\left(1-\alpha_{\text {fis }}\right)(n+g+\delta)$, which is the coefficient of convergence variable in equation (12) and In[fist-fis*]In[fist-1 -fis*] is the growth rate of fiscal variable/ convergence. Thus, the signs and magnitude of the sizes of the estimated parameters in the model equation must tend towards the same direction. Hence, for smooth international comparison, all the variables are expressed in international purchasing power parities (PPP).

Other Methodologies for Macroeconomic Convergence: Analysis of Dispersion: Define the standard deviation of $\mathrm{x}$ countries in the region at time $\mathrm{t}$ as $\sigma_{\mathrm{t}}$. Then one way to assess convergence is to see whether $\sigma$ decreases over time. A formal test involves estimating the regression:

$\sigma_{t}=\alpha+\varphi T+\varepsilon_{t}$

Where $\mathrm{T}$ is a time trend, $\varepsilon$ is a disturbance, and $\alpha$ and $\varphi$ are the parameters to be estimated. Convergence requires that the estimated $\varphi$ to be significantly negative. Equation (16) can be estimated using OLS and this methodology to test convergence is referred to as sigma test or sigma convergence. Sigma convergence states that the dispersion of a series under consideration in a country or across a group country tends to fall over time. In order word, the economies are converging in the sense of sigma, $\sigma$ (standard deviation) if $\sigma_{\mathrm{t}+\mathrm{T}}<\sigma_{\mathrm{t}}$, where $\sigma_{\mathrm{t}}$, is the time $\mathrm{t}$ standard deviation of $\log$ (variable ${ }_{\mathrm{it}}$ ) across $\mathrm{i}$

Stochastic Convergence and Common Trends: The definition of stochastic convergence is based on the concepts of unit roots and cointegration in time series econometric and was introduced by Bernard and Darlauf (1995) in their study of income convergence in a stochastic environment. This study followed used this method based on the environment the study was carried out.

Unit Root Testing: Let $\mathrm{x}_{\mathrm{m}}$ be the annual average of variable $\mathrm{x}$. Then, define the time varying process $\delta_{\mathrm{it}} \equiv \mathrm{x}_{\mathrm{it}}-$ $\mathrm{x}_{\mathrm{mt}}$. In practice $\delta$ is the time varying difference between $\mathrm{x}$ in country i at time $\mathrm{t}$ and some country reference value of $x$ at the same time. A second way to assess convergence is to see whether this time varying difference exhibits any tendency to die over time. Formally, this requires estimating the following equation:

$\delta_{i t}=\alpha+\phi \delta_{i t-1} \varepsilon_{t}$

And test the null hypothesis Ho: $\Phi=1$. This is a standard test for a unit root. Rejection of the null implies that the series $\mathrm{x}$ is converging towards the reference value. This approach to testing convergence is called unit root test.

Analysis of Cointegration: A second notion of stochastic convergence holds that two or more series converge if they share a common stochastic trend; that is, if they are cointegrated. Therefore, the test of convergence amounts to testing for cointegration in the equation:

$x_{i, t}=\beta_{0}+\beta_{1} x_{-i 1, t}+\beta_{2} x_{-i 2, t}+\ldots . .+\beta_{3} x_{-i k, t}+\varepsilon_{t}$

Where $-\mathrm{i}, \mathrm{t}(\mathrm{t}=1-----\mathrm{k})$ denotes the series other than i. Equation (18) will include only series $\mathrm{x}$ that is integrated of order 1 . The determination of the order of integration will be done based on Augmented Dickey-Fuller test (ADF) unit root applied for unit root test methodology. A finding of $p-1$ cointegrating vectors, where $p$ is the total number of series in the equation, denotes full convergence. A finding of less that $\mathrm{p}-1$ cointegrating vectors will denote partial convergence; that is, some series are converging and some are not. If no cointegrating vector is identified, then it shows evidence of no convergence at all. The study employed Johansen procedure. This way of estimating convergence is referred to cointegration test.

Source of Data and Estimation Technique: The study employed time series data for ten countries among the Sub-Sahara African countries for the periods 1981 to 2007. The data obtained were analysed using econometric technique.

\section{Results and Discussion}

The estimated results of the conditional beta convergence as shown in table 1 above indicated that there was a convergence in fiscal balance in Burkina Faso, Cameroon, Nigeria, Rwanda and Uganda since the coefficient 
Table 1: Empirical Analysis of Fiscal Convergence Results

\begin{tabular}{|c|c|c|c|c|c|}
\hline \multicolumn{6}{|c|}{ Selected Countries in SSA } \\
\hline & & & Burkina Faso & Burundi & Cameroon \\
\hline \multirow{4}{*}{ Fiscal Balance } & $\beta$ & & $-0.8156^{*}(0.2085)$ & $-0.0824(0.2106)$ & $-0.4019 * *(0.1970)$ \\
\hline & $\Phi_{1}$ & & $-0.0968(0.1161)$ & $0.0074(0.0268)$ & $0.0011(0.0015)$ \\
\hline & $\Phi_{2}$ & & $-0.1262(0.1748)$ & $-0.3489^{* * *}(0.1855)$ & $0.0003(0.0004)$ \\
\hline & & & $\mathrm{R}^{2}: 0.2034, \mathrm{D} . \mathrm{W}: 2.21$ & $\mathrm{R}^{2}: 0.2222, \mathrm{D} . \mathrm{W}: 2.08$ & $\mathrm{R}^{2}: 0.2317, \mathrm{D} . \mathrm{W}: 1.75$ \\
\hline \multicolumn{6}{|l|}{ Distortionary Tax } \\
\hline & & $\beta$ & $0.2133(0.2224)$ & $-0.2876(0.2233)$ & $-0.7246 *(0.1977)$ \\
\hline & $\Phi_{1}$ & & $0.1878(0.1332)$ & $0.0019(0.0200)$ & $0.0045(0.0061)$ \\
\hline & $\Phi_{2}$ & & $-0.3561(0.2132)$ & $0.0833(0.1420)$ & $-0.0007(0.0001)$ \\
\hline & & & R2: 0.1615, D.W: 1.60 & $\mathrm{R}^{2}: 0.0790, \mathrm{D} . \mathrm{W}: 2.11$ & $\mathrm{R}^{2}: 0.4060, \mathrm{D} . \mathrm{W}: 2.12$ \\
\hline \multirow{5}{*}{ Productive Exp. } & $\mathrm{B}$ & & $-0.0957(0.2329)$ & $-0.0395(0.2121)$ & $0.1707(0.2072)$ \\
\hline & $\Phi_{1}$ & & $0.2683(0.2363)$ & $0.0074(0.0123)$ & $0.0113^{* * *}(0.0059)$ \\
\hline & $\Phi_{2}$ & & $-0.3488(0.3706)$ & $-0.1190(0.0908)$ & $0.0005^{* *}(0.0002)$ \\
\hline & & & $\mathrm{R}^{2}: 0.0975, \mathrm{D} . \mathrm{W}: 2.00$ & $\mathrm{R}^{2}: 0.1698, \mathrm{D} . \mathrm{W}: 2.15$ & $\mathrm{R}^{2}: 0.5059, \mathrm{D} . \mathrm{W}: 1.85$ \\
\hline & & & Kenya & Mauritius & Nigeria \\
\hline \multirow[t]{4}{*}{ Fiscal Balance } & $\beta$ & & $-0.1710(0.2576)$ & $-0.2681(0.2133)$ & $-0.4801^{* *}(0.2038)$ \\
\hline & $\Phi_{1}$ & & $-0.0213(0.0226)$ & $0.1302(0.1115)$ & $0.4584(0.7839)$ \\
\hline & $\Phi_{2}$ & & $0.0002(0.0002)$ & $-0.0002(0.0004)$ & $-0.0007(0.0009)$ \\
\hline & & & $\mathrm{R}^{2}: 0.0945$, D.W: 2.02 & $\mathrm{R}^{2}: 0.1561$, D.W: 2.03 & $\mathrm{R}^{2}: 0.2709, \mathrm{D} . \mathrm{W}: 2.35$ \\
\hline \multirow[t]{5}{*}{ Distortionary } & & Tax & & & \\
\hline & & $\beta$ & $0.2689(0.2568)$ & $-0.2334(0.2681)$ & $0.0148(0.1857)$ \\
\hline & $\Phi_{1}$ & & $-0.0021(0.0265)$ & $0.1640(0.1968)$ & $0.0070(0.0572)$ \\
\hline & $\Phi_{2}$ & & $0.0009(0.0003)$ & $0.0005(0.0006)$ & $-0.0019^{*}(0.0007)$ \\
\hline & & & $\mathrm{R}^{2}: 0.1254, \mathrm{D} . \mathrm{W}: 1.98$ & $\mathrm{R}^{2}: 0.0844, \mathrm{D} . \mathrm{W}: 1.81$ & $\mathrm{R}^{2}: 0.4345, \mathrm{D} . \mathrm{W}: 1.98$ \\
\hline \multirow[t]{5}{*}{ Productive Exp. } & B & & $-0.1449(0.2175)$ & $0.2613(0.1881)$ & $0.4411^{* *}(0.1777)$ \\
\hline & $\Phi_{1}$ & & $0.0297(0.0455)$ & $0.3476(0.2364)$ & $-0.0072(0.0072)$ \\
\hline & $\Phi_{2}$ & & $0.0001^{* *}(0.0005)$ & $0.0018^{* * *}(0.0009)$ & $0.0009(0.0009)$ \\
\hline & & & $\mathrm{R}^{2}: 0.3817, \mathrm{D} . \mathrm{W}: 1.69$ & $\mathrm{R}^{2}: 0.3889, \mathrm{D} . \mathrm{W}: 2.15$ & $\mathrm{R}^{2}: 0.5116, \mathrm{D} . \mathrm{W}: 2.41$ \\
\hline & & & Rwanda & Sierra Leone & South Africa \\
\hline \multirow[t]{4}{*}{ Fiscal Balance } & $\beta$ & & $-0.5360 *(0.1840)$ & $-0.1291(0.2926)$ & $-0.1741(0.2378)$ \\
\hline & $\Phi_{1}$ & & $0.0896(0.1217)$ & $0.1397^{* * *}(0.0739)$ & $0.0010(0.0256)$ \\
\hline & $\Phi_{2}$ & & $-0.0001(0.0001)$ & $0.0006(0.0050)$ & $0.0002(0.0002)$ \\
\hline & & & $\mathrm{R}^{2}: 0.3483, \mathrm{D} . \mathrm{W}: 2.30$ & $\mathrm{R}^{2}: 0.2054, \mathrm{D} . \mathrm{W}: 1.65$ & $\mathrm{R}^{2}: 0.1437, \mathrm{D} . \mathrm{W}: 2.28$ \\
\hline \multicolumn{6}{|l|}{ Distortionary Tax } \\
\hline & & $\beta$ & $0.1905(0.2006)$ & $-0.4277^{* *}(0.1781)$ & $-0.2486(0.2113)$ \\
\hline & $\Phi_{1}$ & & $0.3029^{* * *}(0.1618)$ & $2.0464(1.5391)$ & $-0.0060(0.0321)$ \\
\hline & $\Phi_{2}$ & & $0.0006 *(0.0001)$ & $-0.0472(0.0284)$ & $-0.0005(0.0003)$ \\
\hline & & & R2: 0.5918, D.W: 1.92 & $\mathrm{R}^{2}: 0.7556, \mathrm{D} . \mathrm{W}: 1.80$ & $\mathrm{R}^{2}: 0.1503, \mathrm{D} . \mathrm{W}: 2.02$ \\
\hline \multirow[t]{4}{*}{ Productive Exp. } & $\mathrm{B}$ & & $-0.1113(0.1987)$ & $-0.0048(0.1993)$ & $-0.0344(0.1316)$ \\
\hline & $\Phi_{1}$ & & $0.4477^{* *}(0.1872)$ & $-0.1577(0.5445)$ & $-0.0698(0.0455)$ \\
\hline & $\Phi_{2}$ & & $0.0003(0.0002)$ & $-0.0166(0.0101)$ & $0.0017 *(0.0004)$ \\
\hline & & & R2: 0.2617, D.W: 1.99 & $\mathrm{R}^{2}: 0.3422, \mathrm{D} \cdot \mathrm{W}: 2.42$ & $\mathrm{R}^{2}: 0.6372, \mathrm{D} . \mathrm{W}: 1.91$ \\
\hline \multirow[t]{5}{*}{ Uganda } & & & Fiscal Balance & Distortionary tax & Productive Expenditure \\
\hline & $\mathrm{B}$ & & $-0.6243^{* *}(0.1852)$ & $-0.6201^{* *}(0.2160)$ & $-0.4688^{*}(0.1413)$ \\
\hline & $\Phi_{1}$ & & $-0.2133(0.6311)$ & $-0.6662(0.7112)$ & $-1.1770 * * *(0.6660)$ \\
\hline & $\Phi_{2}$ & & $0.0002(0.0003)$ & $0.0002(0.0003)$ & $0.0011 *(0.0003)$ \\
\hline & & & $\mathrm{R}^{2}: 0.3650$, D.W: 2.38 & $\mathrm{R}^{2}: 0.0812, \mathrm{D} . \mathrm{W}: 1.92$ & $\mathrm{R}^{2}: 0.6330$, D.W: 2.01 \\
\hline
\end{tabular}

Note: * signifies Significant at 1\% level, ${ }^{* *}$ signifies Significant at 5\% level, ${ }^{* * *}$ signifies Significant at 10\% level, Values in parentheses are Standard Errors

Source: Author Computation, 2010

of beta was negative and statistically significant at 5\% level but Burundi, Kenya, Mauritius, Sierra Leone and South Africa had divergence in their fiscal balance indicating that these countries fiscal deficit did not diminishing over-time. This result was an improvement to that of Gilles and Gilles (2005) who found no real convergence among the member of ECOWAS countries than divergence in Nigeria and two other countries due to the issue of poverty trap. 
Table 2: Analysis of Fiscal Variables Gaps

\begin{tabular}{|c|c|c|c|c|c|c|}
\hline Series & Gap/Period & Burkina Faso & Burundi & Cameroon & Kenya & Mauritius \\
\hline \multirow[t]{2}{*}{ Fiscal Balance } & 50 Percent & 2 years & 9 years & 2 years & 4 years & 3 years \\
\hline & 99 Percent & 11 years & 57 years & 12 years & 27 year & 18 years \\
\hline Distortionary & 50 Percent & - & 3 years & 1 year & - & 3 years \\
\hline $\operatorname{tax}$ & 99 Percent & - & 16 years & 7 years & - & 20 years \\
\hline Productive & 50 Percent & 7 years & 18 years & - & 5 years & - \\
\hline Expenditure & 99 Percent & 48 years & 117 years & - & 32 years & - \\
\hline Series & Gap/Period & Nigeria & Rwanda & Sierra Leone & South Africa & Uganda \\
\hline \multirow[t]{2}{*}{ Fiscal Balance } & 50 Percent & 2 years & 2 years & 5 years & 4 years & 4 years \\
\hline & 99 Percent & 10 years & 9 years & 36 years & 27 years & 25 years \\
\hline Distortionary & 50 Percent & - & 4 years & 4years & 3 years & 6 years \\
\hline $\operatorname{tax}$ & 99 Percent & - & 23 years & 15years & 19 years & 39 years \\
\hline Productive & 50 Percent & 2years & 6 years & 69 years & 21 years & 10 years \\
\hline Expenditure & 99 Percent & 9years & 41 years & 461 years & 135 years & 67 years \\
\hline
\end{tabular}

Source: Author's Computation, 2010

The results in table 2 indicate the estimated length of time to eliminate half (50 percent) of the initial fiscal variables gaps and how long it will take to close those fiscal variables gaps. The results of conditional beta convergence showed that it will take two years in Burkina Faso, Cameroon, Nigeria and Rwanda to eliminate half of the initial fiscal balance gap, three years in Mauritius, four years in Kenya, South Africa and Uganda, five years in Sierra Leone and nine years in Burundi, but it will take at least nine years in Rwanda, ten years in Nigeria, eleven years in Burkina Faso, twelve years in Cameroon, eighteen years in Mauritius, twenty-five years in Uganda, twenty-seven years in Kenya and South Africa, thirty-six years in Sierra Leone and fiftyseven years in Burundi to close these fiscal balance gaps completely as supported by the claimed in Mark (2005) that found strong long run convergence in both CFA and SACU countries.

Table 3: Results of Sigma Tests

\begin{tabular}{llll}
\hline $\begin{array}{l}\text { Selected Sub-Saharan } \\
\text { African Countries }\end{array}$ & \multicolumn{2}{c}{ Fiscal Variables } \\
\hline Burkina Faso & & Fiscal Balance & Productive Expenditure \\
Coefficient of time & $-0.1981^{*}(0.0245)$ & $-1.0988^{* * *}(0.4783)$ & $-0.0052(0.0108)$ \\
R-Square & 0.9561 & 0.6376 & 0.0721 \\
D.W & 2.30 & 1.59 & 2.52 \\
Burundi & & $-2.2454(1.1723)$ & $-0.0048(0.0226)$ \\
Coefficient of time & $-0.0347(0.0211)$ & 0.5502 & 0.0149 \\
R-Square & 0.4729 & 2.03 & 2.88 \\
D.W & 2.75 & & \\
Cameroon & & $0.2246(0.6655)$ & $-0.0234(0.0191)$ \\
Coefficient of time & $-0.3263(0.6138)$ & 0.0366 & 0.3326 \\
R-Square & 0.0861 & 2.66 & 2.14 \\
D.W & 2.98 & & \\
Kenya & & $0.6087^{*}(0.1648)$ & $-0.0037(0.0170)$ \\
Coefficient of time & $-0.0155(0.0452)$ & 0.8198 & 0.0156 \\
R-Square & 0.0378 & 2.60 & 3.18 \\
D.W & 2.53 & & \\
Mauritius & & $0.2604(12.0210)$ & $-0.0224^{* * *}(0.0087)$ \\
Coefficient of time & $-0.0058(0.0270)$ & 0.0002 & 0.6912 \\
R-Square & 0.0151 & 2.46 & 3.38 \\
D.W & 2.81 & & \\
Nigeria & & $0.9076(2.9987)$ & $-0.0104(0.0124)$ \\
Coefficient of time & $-0.1761^{* * *}(0.0694)$ & 0.0296 & 0.1894 \\
R-Square & 0.6820 & 1.90 & 2.21 \\
D.W & 2.82 & & \\
\hline
\end{tabular}




\begin{tabular}{|c|c|c|c|}
\hline \multicolumn{4}{|l|}{ Rwanda } \\
\hline Coefficient of time & $0.0145(0.1163)$ & $0.1721(0.3642)$ & $-0.0074(0.0157)$ \\
\hline R-Square & 0.0051 & 0.0693 & 0.0691 \\
\hline D.W & 2.71 & 1.87 & 1.97 \\
\hline \multicolumn{4}{|l|}{ Sierra Leone } \\
\hline Coefficient of time & $-0.2138^{* * *}(0.0730)$ & $-0.5129(0.9513)$ & $0.0523(0.0617)$ \\
\hline R-Square & 0.7408 & 0.0883 & 0.1930 \\
\hline D.W & 2.28 & 2.95 & 2.88 \\
\hline \multicolumn{4}{|l|}{ South Africa } \\
\hline \multicolumn{4}{|l|}{ Coefficient of time } \\
\hline R-Square & $-0.0238^{* *}(0.0060)$ & $-0.2682(0.2024)$ & $-0.0157(0.0196)$ \\
\hline \multirow[t]{2}{*}{ D.W } & 0.8379 & 0.3692 & 0.1767 \\
\hline & 1.62 & 1.97 & 2.32 \\
\hline \multicolumn{4}{|l|}{ Uganda } \\
\hline Coefficient of time & $-0.0012(0.0085)$ & $-0.1322(0.2985)$ & $-0.0018(0.0294)$ \\
\hline R-Square & 0.0068 & 0.0614 & 0.0012 \\
\hline D.W & 3.43 & 2.76 & 3.10 \\
\hline
\end{tabular}

The sigma tests in table 3 on the standard deviation of fiscal balance indicated a significant negative coefficient of time for Burkina Faso, which confirmed the existence of convergence in fiscal balance. Although, the sigma test for Burundi, Sierra Leone, South Africa and Uganda do not signify a significant negative coefficient, this also supported the claims of no convergence in fiscal balance in Burundi and South Africa as stated earlier.

Table 4: Results of Unit Root Test

\begin{tabular}{llll}
\hline Selected Sub-Saharan & \multicolumn{3}{c}{ Fiscal Variables (series deviation from annual mean) } \\
Africa Countries & Fiscal Balance & Distortionary Tax & Productive Expenditure \\
\hline Burkina Faso & $-4.5318^{*}$ & $-4.1746^{*}$ & $-4.3750^{*}$ \\
Burundi & $-3.7646^{*}$ & $-4.5255^{*}$ & $-3.4876^{* *}$ \\
Cameroon & -1.1710 & $-3.4131^{* *}$ & $-3.9515^{*}$ \\
Kenya & -0.2839 & $-3.3730^{* *}$ & $-3.7357^{* *}$ \\
Mauritius & -1.8068 & $-3.5398^{* *}$ & $-3.1078^{* *}$ \\
Nigeria & -1.8357 & $-2.6898^{* *}$ & $-3.9791^{*}$ \\
Rwanda & -1.8756 & $-3.5055^{* *}$ & $-4.3477^{*}$ \\
Sierra Leone & $-5.6494^{*}$ & $-3.5795^{* *}$ & -1.6330 \\
South Africa & $-4.8855^{*}$ & $-9.1309^{*}$ & $-2.7411^{* * *}$ \\
Uganda & $-4.6920^{*}$ & $-3.4582^{*}$ & $-4.1219^{*}$ \\
\hline
\end{tabular}

Note: * signifies Significant at 1\% level; $\quad{ }^{* *}$ signifies Significant at 5\% level; ${ }^{* * *}$ signifies Significant at $10 \%$ level. See Mackinnon (1996) for asymptotic values.

Source: Author's Computation, 2010

The result in the table 4 above was the unit root test as one of the methods of conducting Stochastic Convergence and performed on each of the fiscal variables using series deviation from annual mean in the selected countries. The results revealed that all the countries under study converged in their respective fiscal balance since the result rejected the presence of unit root. In order to fully achieve the stipulated objective of the study, we employed Cointegration technique which was one of the stochastic methods of convergence that took care of the nature of the convergence in macroeconomic variables. The table 5 below showed the results of the Johansen Cointegration test. 
Table 5: Johansen cointegration test results

\begin{tabular}{|c|c|c|c|}
\hline $\begin{array}{l}\text { Selected } \\
\text { Saharan } \\
\text { Countries }\end{array}$ & $\begin{array}{r}\text { Sub- } \\
\text { Africa }\end{array}$ & $\begin{array}{l}\text { Number of Cointegrating Equation with } \\
\text { Level of Significant }\end{array}$ & Nature of Convergence \\
\hline Burkina Faso & & 1 cointegrating equation at $5 \%$ sig. level & Partial Convergence \\
\hline Burundi & & 3 cointegrating equations at $5 \%$ sig. level & Full Convergence \\
\hline Cameroon & & 2 cointegrating equations at $5 \%$ sig. level & Partial Convergence \\
\hline Kenya & & 1 cointegrating equation at $5 \%$ sig. level & Partial Convergence \\
\hline Mauritius & & 2 cointegrating equations at $5 \%$ sig. level & Partial Convergence \\
\hline Nigeria & & No cointegrating equation & None \\
\hline Rwanda & & 1 cointegrating equation at $5 \%$ sig. level & Partial Convergence \\
\hline Sierra Leone & & 2 cointegrating equations at $5 \%$ sig. level & Partial Convergence \\
\hline South Africa & & 2 cointegrating equations at $5 \%$ sig. level & Partial Convergence \\
\hline Uganda & & 3 cointegrating equations at $5 \%$ sig. level & Full Convergence \\
\hline
\end{tabular}

Source: Author's Computation, 2010

The Johansen cointegration test results in table 5 also confirmed the existence of convergence in fiscal variables in the selected countries in sub-Saharan Africa. Countries like Burundi and Uganda indicated full convergence in fiscal variables since the countries had p-1 cointegrating vector indicating that there was a convergence of all the fiscal variables in these countries. While Burkina Faso, Cameroon, Kenya, Mauritius, Rwanda, Sierra Leone and South Africa had partial convergence since finding of less than p- 1 cointegrating vectors emerged meaning that there is no convergence in some fiscal variables while cointegration analysis was not conducted for Nigeria. Since all the fiscal variables employed reject the presence of unit root at actual value except productive expenditure, which does not reject the presence of unit root since the level of fiscal balance, and distortionary taxes are relatively stable and had no tendency to fluctuate uncontrollably and increase steady-state.

\section{Conclusion and Policy Recommendations}

It is evident from the results of the study that the analysis of convergence in fiscal variables among subSaharan Africa countries shows that 60 percent of the selected countries converged in their fiscal variables. These countries are Burkina Faso, Cameroon, Nigeria, Rwanda, Sierra Leone and Uganda while other countries diverged in their fiscal variables. Hence, these countries that converged in their fiscal variables and had similar growth pattern could form economic integration in order to foster the pace of economic development in their respective country. However, with more stringent testing based on economic growth theories, a very slow pace of convergence of fiscal variables could be seen in those countries that diverged. At that rate, unless there was a major structural shift, it will take more than half a century for these countries to converge and thus attain one of the expected outcomes of regional integration initiatives in sub-Saharan Africa countries.

Policy Recommendations: On the basis of the estimation and model results, the following recommendations are therefore proffered; viz; In SSA countries, government should exercise fiscal discipline; this can be achieved through reduction of wasteful spending. With this step, it will be relatively easy to determine the expenditure growth path. Countries should intensify their efforts towards reduction of external indebtedness which has imposed huge debt service payments on their economy as this is a major source of government deficits. The absence of macroeconomic objectives underlying the persistence of deficit should be incorporated into government fiscal policy. Also, efforts should be geared towards identifying beneficiary projects from the deficit and assess their contributions to the growth of the economy in Sub-Saharan Africa countries. Thus, this will make it possible to identify irrelevant projects, and thereby leads to the assignment of priority to better ones.

Finally, as a result of the above findings, the following suggestions are made for further studies: Methodologically, study can be conducted on this research topic using panel data in order to account for common steady-state and estimate convergence using absolute beta convergence test which pave room for collectiveness. Further studies can also conduct their research on regional basis in order to account for 
appropriate possibility for economic integration within the region among African countries such as ECOWAS, SADC etc. Future studies on SSA countries can analyze the relationship between convergence in fiscal variables and economic growth since this study has successfully accounted for convergence in fiscal variables in the region.

\section{References}

Abdoul, A. W. (2004). Growth and Convergence in WAEMU Countries IMF Working Paper View not Representing IMF October.

Anthony, J. V. (2003). Winner and Losers from Regional Integration Agreements. The Economic Journal, 113, 747-761.

Archibald, X. \& Greenidge, K. C. (2003). The Impact of Banking and Fiscal Policies on State-Level Economic Growth. Southern Economic Journal, 66, 367-378.

Barrientos, P. (2007). Theory, History and Evidence of Economic Convergence in Latin America. European Journal of Heart, 10, 115-125.

Barro, R. J. (1990). Government Spending in a Simple Model of Endogenous Growth. Journal of Political Economy, 98(5), 103-26.

Barro, R. J., Mankiw, N. G. \& Sala-i-Martin, X. (1995). Capital Mobility in Neoclassical Models of Growth. American Economic Review, 85(1), 103-115.

Barro, R. J. \& Sala-i-Martin, X. (1992). Convergence. Journal of Political Economy, 100(2), 223-251.

Barro, R. J. \& Sala-i-Martin, X. (1995). Economic Growth, McGraw-Hill, New York.

Ben- Hammouda, H., Karingi, S., Njuguna, A. \& Sadni-Jallab, M. (2007). Does Macroeconomic convergence Lead to Growth? The Case of Africa, African Trade Policy Centre, Economic Commission for Africa.

Bernard, A. and S. Darlauf (1995). convergence in international output. Journal of Applied Econometrics, 10 (2), 97-108.

Bleaney, M., Gemmell, N. \& Kneller, R. (2001). Testing the Endogenous Growth Model: Public Expenditure, Taxation, and Growth over the Long run. Canadian Journal of Economics, 34(1), 36-57.

Boldrin, M. \& Canova, F. (2001). Europe's Regions: Income Disparities and Regional Policies. Economic Policy 16(3)2, 207-53.

Bouvet, F. (2007). Dynamics of regional income inequality in Europe and impact of EU regional policy and EMU. Paper read at the $4^{\text {th }}$ DG ECFIN Annual Research Conference "Growth and income distribution in an integrated Europe: Does EMU make a difference", Brussels.

Buiter, W. H. (2000). Is Iceland an Optimal Currency Area? Working Paper No. 10, Central Bank of Iceland, Reykjavik, August.

Cappelen, A., Castellacci, F., Fagerberg, J. \& Verspagen, B. (2001). The impact of regional support on growth and convergence in the European Union. Paper presented at European Meeting on Applied and Evolutionary Economics, Vienna. 3(4).

Cashin, P. A. (1995). Government Spending, Taxes and Economic growth. IMF Staff Papers, 42(2), 237-269.

Cheshire, P. \& Magrini, S. (2000). Endogenous Processes in European Regional Growth: Convergence and Policy. Growth and Change, 31(4), 455-476.

Darvas, Z., Rose, A. \& Szapáry, G. (2005). Fiscal Divergence and Business Cycle Synchronization: Irresponsibility is Idiosyncratic. NBER Working Paper, 11580.

Durlauf, S. N. \& Quah, D.T. (1999). The New Empirics of Economic Growth. In J.B. Taylor and M. Woodford (eds.), Handbook of Macroeconomics, 1A, Amsterdam: North Holland.

Fischer, M. M. \& Peter, S. (2007). Income Distribution Dynamics and Cross-Regional Convergence in Europe; Spatial filtering and novel stochastic kernel representations. Paper read at The 54th Annual North American Meetings of the Regional science Association International, Savannah, GA, USA.

Gilles, D. \& Gilles, S. (2005). Testing Real Convergence in the ECOWAS Counties in Presence of Heterogeneous Long Run Growth: A panel Data Study. Centre for Research in Economic Development and International Trade, University of Nottingham, October, 2005.

Islam, N. (1995). Growth Empirics: A Panel Data Approach. Quarterly journal of Economics, 110(4), 1127-70.

Islam, N. (2003). What have we Learnt from the Convergence Debate? Journal of Economic Surveys, 17, 309362.

Jacobs, D., Schoeman, N. J. \& van Heerden, J. H. (2002). Alternative definitions of the budget deficit and its impact on the sustainability of fiscal policy in South Africa. The South African Journal of Economics, 
70(3), 543-59.

Jannies, R. (2006). An Analysis of Macro economic Convergence in SADC, University of Pretoria SA Reserve Bank September.

Kaufman, X., Yunfan, W. \& Shaoping, X. (2003). Spatial Panel Data Analysis for China's Regional Per-capita GDP Convergence. Journal of China University of Geosciences, 5, 34-58.

Kneller, R., Bleaney, M. F. \& Gemmel, N. (1999). Fiscal Policy and Growth: Evidence from OECD Countries. Journal of Public Economics, 74, 171-190.

Kneller, R., Bleaney, M. F. \& Gemmel, N. (2001). Testing the Endogenous Growth Model: Public Expenditure, Taxation, and Growth Over the Long Run. Canadian Journal of Economics, 34(1), 36-57.

Mankiw, N. G., Romer, D. \& Weil, D. N. (1992). A Contribution to the Empirics of Economic Growth. The Quarterly Journal of Economics, 107(2), 407-437.

Mark, J. H. W. (2005). Is Long Run Output Convergence Associated with International? Some new evidence for selected African countries._University Journal of Economic Development, 30(2), 67-86.

Ocal \& Ozylldırım. (2004). Income Convergence: a quintile regression approach. Journal of Economic Development, 29(4), 20- 31.

Olivier. J, A., Andrew B. \& Blanchard. (2000). An Intertemporal Model of Saving and Investment. Econometrica, 51(3), 675-92.

Sala-i-Martin, X. (1996). Empirics for Economic Growth and Convergence. European Economic Review, 40, 1835-75.

Sumar, S. \& Jerome, V. (2007). Banking sector integration and competitive CEMAC, IMF Working Paper, January 1st, 2007.

Temple, J. (1999). The New Growth Evidence. Journal of Economic Literature, 37(10), 112-156. 